\title{
Phospholipid fatty acids from Colombian Caribbean sea sponges
}

\author{
Wilson Rodríguez ${ }^{1 *(0)}$, Carmenza Duque $^{3 \oplus}$, Sven Zea $^{2(0)}$, Leonardo Castellanos ${ }^{3 \oplus}$, \\ Freddy $\operatorname{Ramos}^{3 \oplus}{ }^{\oplus}$, Abel M. Forero ${ }^{3 \oplus}$, Oscar Osorno $^{3 \odot}$ \\ ${ }_{1}^{1}$ Universidad de la Amazonia, Programa de Química, (Sede Porvenir Calle 17 Diagonal 17 con Carrera 3F, Florencia, Caquetá, Colombia) \\ 2 Universidad Nacional de Colombia - Sede Caribe - Instituto de Estudios en Ciencias del Mar -CECIMAR (Carretera Circunvalar San Luis \\ Free Town 52 - 44 - San Andrés y Providencia - Colômbia) \\ ${ }^{3}$ Universidad Nacional de Colombia - Sede Bogotá - Facultad de Ciencias - Departamento de Quimica (Av. Carrera 30 \# 45-03 Edif. 451 \\ - Bogotá D.C., Colombia), Cod Postal 111321 \\ *Corresponding author: w.rodriguez@udla.edu.co
}

\section{Abstract}

Five demosponges belonging to the order Axinellida: Axinella corrugata, Dragmacidon alvarezae, Dragmacidon reticulatum, Ptilocaulis walpersi, Myrmekioderma rea and one sponge belonging to the order Scopalinida: Scopalina ruetzleri were analyzed to assess their fatty acid composition in the phospholipid fraction. Additionally, the seasonal and intraspecific variation in fatty acids composition was assessed in $M$. rea and $D$. alvarezae. Fatty acid identification was conducted using an HRGC-MS with an ECL value of methyl ester derivatives, and analyzing their mass spectra. To confirm double bound location, $\mathrm{N}$-acylpyrrolidide derivatives were used studying their mass spectra. In total, 83 fatty acids were identified with chain lengths ranging from C14 to C32. Interestingly, brominated fatty acids were identified, previously suggested for sponges. Polybranched fatty acids such as 4,8,12-trimethyltridecanoic acid (4,8,12-TMTD) and 3,7,11,15-tetramethylhexadecanoic (phytanic acid) were found, without a clear distribution pattern. A predominance of iso-acids (i-15:0 and i-17:0) on anteiso acids were observed. Some seasonal variations in fatty acid (FA) compositions for $M$. rea and D. alvarezae were observed. The hierarchical Clusters Analysis (HCA) showed that the FA composition was speciesspecific but not informative at the family or order level.

Descriptors: Marine natural products, Caribbean sea, Fatty acid methyl esters, N-pyrrolidide derivatives.

\section{INTRODUCTION}

Marine sponges are well known as a prolific source of fatty acids (FA). These compounds showed a broad spectrum of biological activities such as pancreatic lipase inhibitors, with applications in obesity treatment (brominated polyunsaturated FA) (Liang et al., 2014); cytotoxic activity against murine leukemia L1210 cells and against human carcinoma KB cells

Submitted: 09-Feb-2021

Approved: 04-June-2021

Editor: Rubens M. Lopes

(c) (i) 2021 The authors. This is an open access article distributed under the terms of the Creative Commons license.
(6-Bromo-5,9-heptacosadienoic acid) (Bergé and Barnathan, 2005); antifungal activity (very long-chain $\Delta^{5,9} \mathrm{FA}$ and a-methoxylated FA) (Carballeira, 2008); antiprotozoal and antibacterial activity (combination of 2-methoxylation and unsaturation in FA) (Carballeira et al., 2012)( \pm (Orellano et al., 2013), antimicrobials (Polyunsaturated FA) (Kalidasan et al., 2015), and bacterial biofilm inhibitors (oleic acid and cis-2-decenoic acid) (Rabin et al., 2015) among others. Octacosanoic acid is also notable because of its strong cytotoxicity against the Human Caucassian Promyelocytic Leukaemia (HL-60) cell line (Mohamad et al., 2009). Sponge lipids and FA are likely to be a key component of the sponge stress response under climate change (Bennett et al., 2018). 
Sponges have been identified as an interesting source of FA with novel structures, including 2-methyl branched monoenoic fatty acids (Imbs and Rodkina, 2004); methoxylated long-chain fatty acids (LCFA) (Carballeira et al., 2016); odd-numbered very-long-chain LCFA (Řezanka and Sigler, 2009); branched mid-chain FA (Nechev et al., 2004); acetylenic acids (Aratake et al., 2009); methyl branched LCFA (Carballeira et al., 2016); furan FA (Campos et al., 2018); and polyunsaturated FA (PUFA) (Rod'kina, 2005). Interestingly, there are reports of sponges from boreal waters with high content of brominated fatty acids, higher than sponges from the same taxonomic group collected in equatorial waters (Blumenberg and Michaelis, 2007). Previous studies on fatty acids from sponges, collected in the Colombian Caribbean Sea, have revealed the presence of methyl branches in unusual positions ( $\mathrm{C}-5, \mathrm{C}-8, \mathrm{C}-20)$, on fatty acids with length-chains ranging from $\mathrm{C} 18$ to $\mathrm{C} 28$. Axinyssa ambrosia, Dragmaxia undata and Didiscus oxeatus have also had high contents of long-chain a-hydroxy acids and low contents of long-chain fatty acids, especially in D. undata. In addition, brominated FA were also observed in A. ambrosia (Rodríguez et al., 2010).

Marine lipidology searches for new FA structures; new sources of polyunsaturated fatty acids (PUFA) of biological interest; FA roles in cell membranes; biosynthetic pathways, and developing trophic biomarkers in ecosystems (Bergé and Barnathan, 2005); and also their chemotaxonomic significance. Usually, FA isolated from marine sponges have long chains (>C24), but there are few studies on fatty acid composition significance in chemotaxonomy (Rod'kina, 2005). Examples of the utility include the proposed use of the branched FA 4,8,12-trimethylltridecanoic acid as a chemical marker for the Clionaidae and Spirastrellidae families (Erpenbeck and Van Soest, 2007). A review of the distribution of long-chain FA (LCFA) in the three classes of sponges revealed more proximity between Hexactinellida $\left(\right.$ LCFA $>C_{28}$ ) and Demospongiae (LCFA, $\mathrm{C}_{24}-\mathrm{C}_{28}$ ); and less relationship with Calcarea, which lacks long-chain fatty acids (Erpenbeck and van Soest, 2005). Another study showed that FA profiles of deep-sea sponges can be used as chemotaxonomic markers and support the concept that sponges acquire building blocks from their endosymbiotic bacteria (de Kluijver et al., 2021). In contrast to shallow-water sponges that are dominated by PUFA with a high percentage of LCFAs (C24-C30), the deep-sea sponges were found to be rich in saturated fatty acids (C14-C20) (Zivanovic et al., 2011).

Continuing our research on fatty acids of marine sponges from the Colombian Caribbean Sea (Castellanos and Duque, 2008; Rodríguez et al., 2010), the aim of this study was to determine phospholipid fatty acid composition of the sponges Axinella corrugata, Dragmacidon alvarezae, Dragmaciodn reticulatum, Ptilocaulis walpersi, Myrmekioderma rea and Scopalina ruetzlei in order to detect regularities or novelties, study the seasonal and intraspecific variation for M. rea and D. alvarezae, and explore if the FA composition in the studied sponges can be used as a chemotaxonomic marker at the species and higher taxonomic levels.

\section{METHODS}

\section{Collection of sponges}

Samples of sponges were collected through SCUBA diving in several places around Santa Marta, Colombian Caribbean (Table 1) (Vega-Sequeda et al., 2008)bands of $10 \times 1 \mathrm{~m}$ and $10 \times 2 \mathrm{~m}$ were used, respectively. A total of 33 species of hard corals were registered. Algae and corals were the components with major cover, nonetheless, averages varied widely in the study area (coral= $4.0 \pm 0.9 \%-62.0 \pm 7.2 \%$; algae $=30.6 \pm 11.0 \%-78.3 \pm 3.0 \%$. The sponges were washed with sterile sea water, carefully cleaned of epibiotic organisms and finally frozen $\left(-20^{\circ} \mathrm{C}\right)$. The sponges were identified and classified by $\mathrm{Dr}$. Sven Zea, and reference specimens are available at the Makuriwa Colombian Marine Natural History Museum, Marine and Coastal Research Institute INVEMAR in Santa Marta. Species D. alvarezae and D. reticulatum were described by (Zea and Pulido, 2016). The frozen material was transported to Bogota by air preserving the cold chain.

\section{EXTRACTION AND ISOLATION OF PHOSPHOLIPID FRACTION}

The cleaned sponges were cut into small pieces and extracted with $\mathrm{CHCl}_{3}-\mathrm{MeOH}$ (1:1) to obtain the total lipid fraction. Neutral lipids, glycolipids and phospholipids were separated by column chromatography on silica gel (60-200 mesh) from the total lipidic fraction using a previously reported procedure 
Table 1. Studied marine sponges indicating family, species, location, depth and specimen number. All the samples were collected in the Santa Marta area, Caribbean coast of Colombia.

\begin{tabular}{lcccc}
\hline Family & Species & Place & Depth $(\mathbf{m})$ & Specimens \\
\hline \multirow{2}{*}{ Axinellidae } & Axinella corrugata & Ensenada Guachaquita & 15 & Several \\
& Dragmacidon alvarezae & Punta Aguja $\left(11^{\circ} 11^{\circ} \mathrm{N} ; 74^{\circ} 11^{\prime} \mathrm{W}\right)$ & $15-22$ & 5 \\
& Dragmacidon reticulatum & Punta Aguja $\left(11^{\circ} 18^{\circ} \mathrm{N} ; 74^{\circ} 11^{\prime} \mathrm{W}\right)$ & 15 & 2 \\
& Ptilocaulis walpersi & Ensenada Granate $\left(11^{\circ} 15^{\prime \prime} \mathrm{N} ; 74^{\circ} 7^{\prime} \mathrm{W}\right)$ & $15-18$ & Several \\
Heteroxyidae & Myrmekioderma rea & Bahía de Chengue $\left(11^{\circ} 17^{\prime \prime} \mathrm{N} ; 74^{\circ} 08^{\prime} \mathrm{W}\right)$ & 21 & 3 \\
Scopalinidae & Scopalina ruetzleri & El Morro $\left(11^{\circ} 14^{\prime \prime} \mathrm{N} ; 74^{\circ} 13^{\prime} \mathrm{W}\right)$ & 6 & Several \\
\hline
\end{tabular}

(Carballeira et al., 2007). The phospholipidic fraction (methanolic fraction) was kept in nitrogen at $-10^{\circ} \mathrm{C}$ in $\mathrm{CHCl}_{3}: \mathrm{MeOH}(1: 1)$, with $0.002 \%$ of 2,6-di-tertbutyl4-methylphenol (BHT) as an antioxidant until their derivatization for GC-MS analysis. For intraspecific variation, the same procedure was done (Table 2). For the data in Table 3, the sponge specimens were pooled to have a sufficient quantity of sample for chemical analyses.

\section{FAMES AND $\mathbf{N}$-ACYLPYRROLIDIDES DERIVATIVES}

The fatty acids of the phospholipids were transformed into their methyl esters (FAME) by reaction, under reflux, of the phospholipid fraction $(100 \mathrm{mg}$ ) with methanolic $\mathrm{KOH} 2 \mathrm{~N} \mathrm{(3} \mathrm{ml,} 4 \mathrm{~h}$ ), followed by addition $3 \mathrm{~mL}$ of methanolic boron trifluoride 14\% (Merck $\left.{ }^{\mathrm{TM}}\right)$. This reaction mixture was then stirred (360 rpm) for $2 \mathrm{~h}$ at $60^{\circ} \mathrm{C}$. The reaction mixture was monitored with thin layer chromatography using benzene/ethyl acetate $(10: 2 \mathrm{v} / \mathrm{v})$ as the mobile phase and methyl stearate as standard FAME. The organic fractions were obtained by extraction with benzene (5 mL, 3 times), and dried over anhydrous $\mathrm{Na}_{2} \mathrm{SO}_{4}$. Finally, the FAME were purified by column chromatography on silica gel eluting with hexane/diethyl ether 10:1. The purified FAME fraction was stored at $-20^{\circ} \mathrm{C}$.

To determine the double-bonds and methyl-branching positions in fatty acid chain, $\mathrm{N}$-acylpyrrolidide derivatives were obtained as has been suggested by (Carballeira et al., 2007). These amide derivatives were prepared by direct treatment of FAME fractions ( $20 \mathrm{mg}$ ) with pyrrolidine/ acetic acid $(10: 1)(2 \mathrm{ml})$ for $2 \mathrm{~h}$ at $100^{\circ} \mathrm{C}$. Pyrrolidine $\left(\right.$ Merck $^{\mathrm{TM}}$ ) reagent was distilled before use. The reaction was monitored with thin layer chromatography using benzene/ethyl acetate $(10: 2 \mathrm{v} / \mathrm{v})$ as the mobile phase, and $\mathrm{N}$-stearoyl pyrrolidide as the reference compound. The reaction mixture was purified by CC (silica gel, hexane/diethyl ether 1:2). The resulting methyl esters and $\mathrm{N}$-acylpyrrolidide fractions were analyzed with high resolution gas chromatography coupled mass spectrometry (HRGC-MS).

\section{High Resolution Gas chromatography-mass spec- TROMETRY (HRGC-MS) ANALYSES}

For the HRGC-MS analysis, a Shimadzu GC-17A chromatograph (Kyoto, Japan) equipped with a crosslinked HP-1 fused silica capillary column (25 m x 0.25 $\mathrm{mm}$ i.d.) operating at $70 \mathrm{eV}$ was employed. For FAME analysis, $1 \mu \mathrm{L}$ of a $1 \mathrm{mg} / \mathrm{mL}$ solution in acetone was injected in split mode (1:30), while the temperature of the injector was kept at $300^{\circ} \mathrm{C}$. Helium, 5.0 grade, was used as carrier gas, maintaining a $1 \mathrm{~mL} / \mathrm{min}$ flux. Temperature was kept at $135^{\circ} \mathrm{C}$ for $4 \mathrm{~min}$, followed by a temperature ramp of $2^{\circ} \mathrm{C} / \mathrm{min}$ until $280^{\circ} \mathrm{C}$, maintaining this temperature for $15 \mathrm{~min}$. Detector temperature was set at $300^{\circ} \mathrm{C}$.

The fatty acid methyl esters were identified by its retention times in capillary $\mathrm{GC}$, using equivalent chain length (ECL) (Zhang et al., 2010)a method was developed to search all saturated fatty acid methyl esters in the sample, subsequently calculate the $\mathrm{ECL}$ value of each fatty acid, and finally identify the molecular structure for each component by comparing the ECL of the interest and that in the customised database. Our method was applied to analyse the fatty acid composition of Eucommia ulmoides seed oil. The results show that major polyunsaturated fatty acids are a-linolenic acid $(56.5093 \%$ of total fatty acids, TFAs, and by their FAME mass spectral analysis (Mjøs, 2004), with further comparison with standards 
Table 2. Marine sponges collected to study of interspecific variation in the phospholipid fatty acid composition. All the samples were collected in the Santa Marta area, Caribbean coast of Colombia.

\begin{tabular}{lcccc}
\hline Family & Species & Place & Depth (m) & Specimens \\
\hline Axinellidae & Dragmacidon alvarezae & Punta Aguja $\left(11^{\circ} 18^{\prime \prime} \mathrm{N} ; 74^{\circ} 11^{\prime} \mathrm{W}\right)$ & $15-22$ & 3 \\
& & El Morro $\left(11^{\circ} 14^{\prime \prime} \mathrm{N} ; 74^{\circ} 13^{\prime} \mathrm{W}\right)$ & $11-22$ & 4 \\
Heteroxyidae & Myrmekioderma rea & El Morro $\left(11^{\circ} 14^{\prime \prime} \mathrm{N} ; 74^{\circ} 13^{\prime} \mathrm{W}\right)$ & $15-23$ & 4 \\
& & Bahía de Chengue $\left(11^{\circ} 17^{\prime \prime} \mathrm{N} ; 74^{\circ} 08^{\prime} \mathrm{W}\right)$ & 22 & 2 \\
& & Bahia de Chengue $\left(11^{\circ} 17^{\prime \prime} \mathrm{N} ; 74^{\circ} 08^{\prime} \mathrm{W}\right)$ & 1 & 4 \\
\hline
\end{tabular}

Table 3. Phospholipid fatty acid composition of marine sponges from the Colombian Caribbean Sea.

\begin{tabular}{|c|c|c|c|c|c|c|c|c|}
\hline & Sponge & & 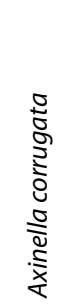 & 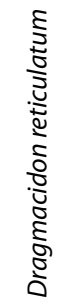 & 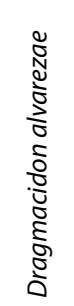 & 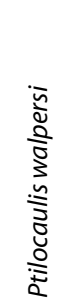 & 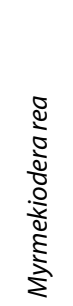 & 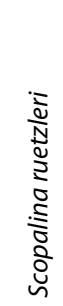 \\
\hline & Fatty acid & $\mathrm{ECL}$ & \multicolumn{6}{|c|}{ Relative abundance (\%) } \\
\hline 1 & n-tetradecanoic (n-14:0) & 14.00 & & 1.0 & 2.0 & 4.7 & 2.0 & 6.2 \\
\hline 2 & 4, 8,12-trimethyltridecanoic $(r-16: 0)$ & 14.51 & & 4.6 & 6.5 & 11.3 & 1.5 & 7.0 \\
\hline 3 & 13-methytetradecanoic (i-15:0) & 14.64 & 0.9 & 4.1 & 0.4 & 0.8 & 1.7 & 0.5 \\
\hline 4 & 12-methyltetradecanoic (ai-15:0) & 14.71 & & 0.4 & 0.6 & 0.6 & 1.5 & 0.6 \\
\hline 5 & n-pentadecanoic (n-15:0) & 15.00 & 0.9 & 0.6 & 0.9 & 1.7 & 1.3 & 5.8 \\
\hline 6 & 14-methylpentadecanoic (i-16:0) & 15.66 & & & & 0.9 & 0.9 & 1.0 \\
\hline 7 & 9-hexadecenoic (16:1) & 15.76 & 3.3 & 1.7 & 2.1 & 5.8 & 1.7 & 1.6 \\
\hline 8 & n-hexadecanoic (n-16:0) & 16.00 & 11.3 & 15.1 & 10.2 & 13.4 & 12.1 & 12.4 \\
\hline 9 & 15-methyl-9-hexadecenoic (i-17:1) & 16.32 & 0.6 & & & & 1.4 & \\
\hline 10 & 10-methylhexadecanoic $(\mathrm{r}-17: 0)$ & 16.40 & 0.7 & & & & 5.1 & \\
\hline 11 & 8-heptadecenoic (17:1) & 16.49 & & & 0.9 & & & \\
\hline 12 & 15-methylhexadecanoic (i-17:0) & 16.63 & 1.0 & 0.5 & 0.5 & 0.2 & 1.2 & \\
\hline 13 & 14-methylhexadecanoic (ai-17:0) & 16.71 & & 0.6 & 0.9 & 1.1 & 1.3 & 0.9 \\
\hline 14 & 9-heptadecenoic (17:1) & 16.81 & 1.1 & 1.1 & 1.4 & 0.6 & & 1.1 \\
\hline 15 & n-heptadecanoic (n-17:0) & 17.00 & & 0.8 & 0.8 & 0.8 & 1.6 & 2.5 \\
\hline 16 & 2-methoxyhexadecanoic (2-OMe-16:0) & 17.24 & 0.4 & & & & & \\
\hline 17 & 16-methylheptadecanoic (i-18:0) & 17.61 & & & & 5.7 & & \\
\hline 18 & $6,9,12,15$-octadecatetraenoic (18:4) & 17.43 & & & 1.9 & & & \\
\hline 19 & 9,12-octadecadienoic (18:2) & 17.60 & 2.2 & 0.8 & 1.2 & 1.6 & 1.1 & 1.1 \\
\hline 20 & 5-octadecenoic (18:1) & 17.68 & & & 4.7 & & & \\
\hline 21 & 9-octadecenoic (18:1) & 17.71 & 4.9 & 4.2 & 2.9 & 4.9 & 3.0 & 3.7 \\
\hline 22 & $3,7,11,15$-tetrametilhexadecanoic $(r-20: 0)$ & 17.75 & 18.6 & & & & 14.9 & 1.9 \\
\hline 23 & 11-octadecenoic (18:1) & 17.79 & & 1.8 & & & 3.4 & 0.5 \\
\hline 24 & n-octadecanoic (n-18:0) & 18.00 & 6 & 8.3 & 6 & 9.2 & 8 & 11 \\
\hline 25 & 11-metiloctadecanoic ( $r-19: 0)$ & 18.45 & 1.3 & 1 & & & & \\
\hline 26 & 15-metiloctadecanoic $(r-19: 0)$ & 18.57 & 0.7 & 0.6 & 0.7 & & & \\
\hline
\end{tabular}




\section{Continued table 3.}

\begin{tabular}{|c|c|c|c|c|c|c|c|c|}
\hline 27 & 16-metiloctadecanoic (ai-19:0) & 18.70 & & 0.5 & 0.3 & & & \\
\hline 28 & 17-metiloctadecanoic (i-19:0) & 18.63 & & & 0.3 & & 0.9 & \\
\hline 29 & 11-nonadecenoic (19:1) & 18.81 & & 0.4 & & 0.5 & & \\
\hline 30 & n-nonadecanoic (n-19:0) & 19.00 & & 0.7 & 0.6 & 0.7 & & 7.0 \\
\hline 31 & $5,8,11,14$-icosatetraenoic $(20: 4)$ & 19.23 & 3.6 & & 3 & 2.8 & 2.7 & \\
\hline 32 & 8,11,14,17-icosatetraenoic (20:4) & 19.26 & & & 1.5 & & 2.8 & \\
\hline 33 & $8,11,14$-icosatetraenoic $(20: 3)$ & 19.41 & & & 0.5 & & & \\
\hline 34 & 6,11-icosadienoic (20:2) & 19.58 & 1.8 & & 1.1 & & & \\
\hline 35 & 18-metilnonadecanoic (i-20:0) & 19.63 & & & & 1.1 & & \\
\hline 36 & 11-icosenoic $(20: 1)$ & 19.67 & 1.3 & & & & & \\
\hline 37 & 13-icosenoic $(20 ; 1)$ & 19.74 & 0.6 & 0.5 & 0.7 & 0.5 & & \\
\hline 38 & n-icosanoic (20:0) & 20.00 & 0.6 & 3.7 & 1.4 & 1.7 & & 1.8 \\
\hline 39 & 13-heneicosenoic (21:1) & 20.84 & 0.8 & & & & & \\
\hline 40 & $\mathrm{n}$-heneicosanoic $(\mathrm{n}-21: 0)$ & 21.00 & & & & 0.8 & & 0.6 \\
\hline 41 & $4,7,10,13,16,19$-docosahexaenoic $(22: 6 n-3)$ & 21.10 & & & 4.1 & & & \\
\hline 42 & $10,13,16,19$-docosatetraenoic $(22: 4 n-3)$ & 21.22 & & & 0.5 & & & \\
\hline 43 & $7,10,13,16$-docosatetraenoic $(22: 4 n-6)$ & 21.13 & 0.9 & & 0.4 & & & \\
\hline 44 & n-docosanoic (n-22:0) & 22.00 & & 1.2 & 1 & 1.4 & & 3.1 \\
\hline 45 & 16-tricosenoic (23:1) & 22.71 & 1.1 & 0.6 & & & & 0.8 \\
\hline 46 & $\mathrm{n}$-tricosanoic $(23: 0)$ & 23.00 & & 0.3 & 0.4 & 0.5 & 0.4 & 0.6 \\
\hline 47 & 16-tetracosenoic (24:1) & 23.90 & & & & 1.6 & & \\
\hline 48 & 17-tetracosenoic (24:1) & 23.77 & & 1.5 & 2.4 & & & \\
\hline 49 & $\mathrm{n}$-tetracosanoic $(\mathrm{n}-24: 0)$ & 24.00 & & 0.8 & 2.8 & 1.1 & 1.1 & 3.1 \\
\hline 50 & 5,9-pentacosadienoic (25:2) & 24.45 & 2.2 & 0.7 & 0.9 & & 2.2 & \\
\hline 51 & 19-methyltetracosanoic $(r-25: 0)$ & 24.57 & & & & & 0.5 & \\
\hline 52 & 9-pentacosenoic (25:1) & 24.66 & 0.5 & & & & & \\
\hline 53 & 23-methyl-5,9-tetracosadienoic (i-25;2) & 24.08 & & & & & 0.5 & \\
\hline 54 & 18-pentacosenoic (25:1) & 24.87 & 0.1 & 2.8 & & & & \\
\hline 55 & $\mathrm{n}$-pentacosanoic $(\mathrm{n}-25: 0)$ & 25.00 & & & & 0.4 & 0.3 & \\
\hline 56 & 2-hydroxitetracosanoic (2-OH-24:0) & 25.27 & 0.6 & & & & 0.8 & \\
\hline 57 & 5,9-hexacosadienoic (26:2) & 25.50 & 25.6 & 11.8 & 14.8 & 1.2 & 6.2 & 2.3 \\
\hline 58 & 9-hexacosenoic (26:1) & 25.63 & 0.5 & 1 & 1.8 & 1 & & \\
\hline 59 & 17-hexacosenoic (26:1) & 25.73 & & 0.9 & 1.5 & 2.5 & 0.6 & 0.6 \\
\hline 60 & 23-methyl-5,9-pentacosadienoic (ai-26:2) & 25.22 & & & & & 0.5 & \\
\hline 61 & 19-hexacosenoic (26:1) & 25.77 & 0.4 & 1.8 & 1.5 & 0.4 & & \\
\hline 62 & n-hexacosanoic (26:0) & 26.00 & 0.5 & & 1.6 & 0.8 & 0.4 & 1.2 \\
\hline 63 & 2-hydroxipentacosanoic (2-OH-25:0) & 26.25 & 0.5 & & & & & \\
\hline 64 & 5,9-heptacosadienoic (27:2) & 26.50 & 0.5 & 1.2 & 2.1 & 1.1 & 0.7 & 1.6 \\
\hline 65 & 6-Bromo-23-methyl-5,9-tetracosadienoic (6-Br-i-25:2) & 26.57 & 0.3 & & & & & \\
\hline 66 & 19-methylhexacosanoic $(r-26: 0)$ & 26.50 & & & & & 1.8 & \\
\hline 67 & 19-heptacosenoic (27:1) & 26.92 & & 0.8 & & & & \\
\hline 68 & $\mathrm{n}$-heptacosanoic $(\mathrm{n}-27: 0)$ & 27.00 & & & & 0.5 & & \\
\hline 69 & 6-Bromo-5,9-pentacosadienoic (6-Br-25:2) & 26.96 & 0.3 & & & & 0.3 & \\
\hline
\end{tabular}


Continued table 3.

\begin{tabular}{|c|c|c|c|c|c|c|c|c|}
\hline 70 & 26-methyl-5,9-heptacosadienoic (i-28:2) & 27.20 & & & & 0.4 & & 0.3 \\
\hline 71 & 25-methyl-5,9-heptacosadienoic (ai-28:2) & 27.23 & & & & & & 0.8 \\
\hline 72 & 2-hydroxihexacosanoic (2-OH-26:2) & 27.30 & 0.3 & & & & & \\
\hline 73 & $5,9,21$-octacosatrienoic $(28: 3)$ & 27.35 & & & & 1 & & \\
\hline 74 & 5,9-octacosadienoic (28:2) & 27.50 & 0.4 & & 0.4 & 5.1 & & 11.9 \\
\hline 75 & 6-Bromo-24-methyl-5,9-pentacosadienoic (6-Br-i-26:2) & 27.60 & 0.4 & & & & & \\
\hline 76 & 6.Bromo.5,9.hexacosadienoic (6-Br-26:2) & 28.17 & & 16.8 & 8 & & 8 & \\
\hline 77 & 6-Bromo-5,9-heptacosadienoic (6-Br-27:2) & 29.04 & & 2.2 & 1.4 & & 1.4 & \\
\hline 78 & 5,9-nonacosadienoic (29:2) & 28.54 & & & & 0.7 & & 0.5 \\
\hline 79 & 2-methoxyhexacosatetraenoic (2-OMe-26:4) & 28.61 & & & & & & 1.1 \\
\hline 80 & 5,9,23-triacontatrienoic (30:3) & 29.33 & & & & 4.4 & & \\
\hline 81 & n-triacontanoic (n.30:0) & 30.00 & & & & 1.4 & & \\
\hline 82 & dotriacontenoic (32:1) & & & & & & 0.5 & \\
\hline 83 & dotriacontanoic (32:0) & & & & & 0.6 & & \\
\hline
\end{tabular}

(C12-C24) and with those of published data (LIPID MAPS; Rodríguez et al., 2010). The abundance relative of each FAME based peak area/total area ratio is reported. For pyrrolidide derivatives, the temperature program started at $200^{\circ} \mathrm{C}$ for $4 \mathrm{~min}$, followed by a temperature ramp of $2^{\circ} \mathrm{C} / \mathrm{min}$ until $295^{\circ} \mathrm{C}$, then maintaining this temperature for $30 \mathrm{~min}$. Others HRGCMS conditions were the same as for FAME capillary chromatographic analysis. The branches and double bond positions in $\mathrm{N}$-acylpyrrolidide fatty acids was determined by comparison with those of published data (Rodríguez et al., 2010).

\section{Statistical ANALYSES}

Multivariate data analysis (MVDA data analysis) and hierarchical cluster analysis (HCA) using UVN scaling were performed with SIMCA-P+ software (version 14.1, Umetrics, Umea, Sweden).

\section{RESEARCH PERMITS}

Ministerio de Ambiente y Desarrollo Sostenible (Colombia) granted permission to collect samples and carry out this research (Permission number 4 of 10/02/ and CONTRATO DE ACCESO A RECURSOS GENÉTICOS Y SUS PRODUCTOS DERIVADOS Nr. 244).

\section{RESULTS}

\section{FATTY ACID COMPOSITION OF THE STUDIED SPONGES}

In this study, 83 fatty acids were identified with chain lengths ranging from $C_{14}$ to $C_{32}$. In general, the predominance of iso-acids (10.7-23\%) on anteiso acids $(\leq 2.8)$ were observed. The presence of monobrominated $F A$ ranging from $C_{25}-C_{27}(\leq 19 \%)$, monohydroxylated $\mathrm{FA}$ ranging from $\mathrm{C}_{24}-\mathrm{C}_{26}(\leq 1.4 \%)$ and monomethoxylated $F A\left(C_{16}\right.$ and $\left.C_{26}\right)(\leq 1.1 \%)$ long chain fatty acids was observed, and the presence of unsaturated $\Delta^{5,9}$ fatty acids (13.9-32.7\%) was very common. In all evaluated sponges, the predominance of short chain FA $(<C 22,54.2-72.8 \%)$, normal chain (55.8-85.9\%) and saturated chain FA (55.7-72.3\%) was observed. For $D$. alvarezae 49 FA were identified, while for $S$. ruetzleri only 32 compounds were characterized (Table 3 ).

The sponge $A$. corrugata had a higher content of phytanic acid (18.6\%) and a-hydroxy acids (1.4\%). D. reticulatum had the highest content of long chain FA (45.8\%), monobrominated acids (14.2\%) and $\Delta^{5,9}$ unsaturation system (29.9\%). D. alvarezae stood out because of its high content of monounsaturated FA (20.3\%), polyunsaturated fatty acids $(11.9 \%)$ and unsaturated FA (43.9\%). M. rea had a high content of branched chain FA (44.2\%), isoacids (23\%), anteiso acids (2.8\%) and mid chain branched acids (7.4\%). The a-methoxylated fatty acids were present in A. corrugata $(0.4 \%)$ and S. ruetzleri (1.1\%). The former also showed the highest odd chain FA content (22.5\%) (Table 3). M. rea had highest content of isoacids (23\%) and anteiso acids (2,8\%) followed by $A$. corrugata (isoacids $21.8 \%$ ) and P. walpersi (isoacids $20.4 \%$ ) (Table 3 ).

In contrast, $A$. corrugata showed a high content of phytanic acid (18.6\%), and $M$. rea had a high content of branched chain FA $(44.2 \%)$, isoacids (23\%), 
anteiso acids (2.8\%) and mid chain branched acids (7.4\%) (Table 3). The Caribbean sponges studied here showed a low content of FA bearing bromine ( $\leq 19 \%$, Table 3). The sponges A. corrugata and S. ruetzleri reported C-2 methoxylated FA content of $1.1 \%$ (Table 3). C-2 hydroxylated FA were only detected at C-2 in A. corrugata (1.1\%) between chain lengths of $C_{24}$ to $\mathrm{C}_{26}$

SEASONAL AND INTRASPECIFIC VARIATION OF FATTY ACIDS

The effect of the coefficient of seasonal variation (CV) on the content of phospholipid fatty acids in the M. rea sponge ranged from $12.2 \%$ to $90.3 \%$. In the $D$. alvarezae sponge, the seasonal CV ranged between $6.0 \%$ and $106.1 \%$. The intraspecific CV (different specimens $A, B$, and $C$ collected on the same date) in $D$. alvarezae ranged from $0 \%$ to $132.4 \%$, showing high variability in FA content among the same species (Table 4).

\section{Hierarchical Clusters Analysis}

To evaluate if sponge FA contents are species specific even when there is seasonal and intraspecific variation, a multivariate data analysis (MVDA) was utilized. The analysis of the FA composition in the samples studied was performed using a Hierarchical Cluster Analysis (HCA-Ward distances) (Figure 1), generating a model with two principal components (PCs), representing $55.5 \%$ of the variance of the included data, with a correlation value of $0.654\left(R^{2}\right)$ and a predictive power of $0.498\left(Q^{2}\right)$. In general terms, all species stood out separately in their overall FA composition. Also, there is a good clustering for sponges collected on the same date $(D$. alvarezae $A, B$, and $C$ replicates) and for samples of same species collected at different times (D. alvarezae, and M. rea). However, the FA composition does not serve to discriminate at higher taxonomic levels in the current classification of sponges, as the profile of S. ruetzleri's, a sponge from the order Scopalinida, is intermingled among the species of the order Axinellida. Aside from this, however, families Axinellida (A. corrugata, D. alvarezae, $D$. reticulatum and $P$. walpersi), and Heteroxyidae (M. rea) were separated by their FA composition.

\section{DISCUSSION}

The fatty acids of phospholipid fraction were identified in this study by the equivalent chain-length
$(E C L)$ value of their methyl esters (de Kluijver et al., 2021); and by mass spectra analysis of the methyl esters and the $\mathrm{N}$-acylpyrrolidide derivatives for each compound (Santalova and Denisenko, 2017). These results are due to the fatty acids isolated from marine organism being diverse in structure and chain length (Table 3). There are some FA unique for bacterial symbionts, which live associated to marine sponges. Consequently, FA have been used as biomarkers for the presence in sponge tissues, i. e. recording for bacteria, i15:0, ai15:0, i17:0, and ai17:0); for diatoms, 14:0, 16:1(9), and 20:5(5,8,11,14,17); and for dinoflagellates 16:0, 18:0, 18:1(11), and 22:6(4,7,10,13,16,19) (Koopmans et al., 2015). Our results suggest a high predominance of bacteria as symbionts in the sponges studied here.

The high content of polyunsaturated FA 22:6 in D. alvarezae suggests the presence of dinoflagellates and microalga as the predominant symbionts (Yang et al., 2017). The presence of short chain FA (14:0, 16:0 and 18:0) is associated to diatoms and dinoflagellates, widespread in all studied sponges, showing that these microorganisms are common symbionts. This implies that FA precursors released from chemo- as well as heterotrophic microbes in sponges contributed to the synthesis of very long chain fatty acids (VLCFA's), identifying sponge-associated bacteria as symbionts of the sponge (van Duyl et al., 2020). It was reported that sponges acquire building blocks from their endosymbiotic bacteria (de Kluijver et al., 2021). The presence of LCFA, known as demospongic acids $\left(\geq C_{23}\right.$ ), have been used as sponge biomarkers in different sponge taxa. For instance Haliclona species are characterized by the presence of FA 28:3, 25:2, and 24:1; Aplysina aerophoba by the presence of 22Me-28:2, 30:3, and 28:3, while Dysidea avara included FA such as 26:2, 25:3, 24:1, and ai-23:0. These compounds have been used to determine metabolic rates in sponges of Demospongiae (Koopmans et al., 2015).

With respect to the FA composition found in the present study (Table 3 ), we can see the sequence 14:0-16:0-18:0-20:0-22:0-24:0-26:0 and 16:1-18:120:1-24:1-26:1 occurred, indicating that our results are agree with currently accepted pathways for the main very long-chain non-methylene-interrupted FAs (>C24) (Kornprobst and Barnathan, 2010). However, for sponges of class Calcarea, the high 
Table 4. Seasonal and intraspecific variation of phospholipid fatty acids in sponges Myrmekioderma rea and Dragmacidon alvarezae.

\begin{tabular}{|c|c|c|c|c|c|c|c|c|c|c|c|c|}
\hline & \multirow{3}{*}{$\begin{array}{c}\text { Sponge } \\
\text { Date } \\
\text { Fatty acid }\end{array}$} & \multicolumn{4}{|c|}{ Myrmekioderma rea } & \multicolumn{7}{|c|}{ Dragmacidon alvarezae } \\
\hline & & May & Nov & \multicolumn{2}{|l|}{ Apr } & \multicolumn{3}{|c|}{ May } & \multicolumn{2}{|r|}{ Feb } & \multicolumn{2}{|l|}{ Sep } \\
\hline & & \multicolumn{3}{|c|}{ Relative abundance (\%) } & \multirow[t]{2}{*}{ CV (\%) } & \multicolumn{3}{|c|}{ Relative abundance (\%) } & \multirow[t]{2}{*}{ CV (\%) } & \multicolumn{2}{|c|}{$\begin{array}{c}\text { Relative } \\
\text { abundance (\%) }\end{array}$} & \multirow[t]{2}{*}{ CV (\%) } \\
\hline & & & & & & $A$ & B & $C^{*}$ & & & & \\
\hline 1 & $n-14: 0$ & 2.7 & 1.8 & 1.5 & 29.9 & 2.0 & 2.1 & 3.3 & 29.3 & 2.2 & 0.4 & 74.4 \\
\hline 2 & 4, 8,12-triMe-13:0 & 1.1 & 2.7 & 0.6 & 74.2 & 4.8 & 4.1 & 17.3 & 85.0 & 5.5 & 1 & 106.1 \\
\hline 3 & $\mathrm{i}-15: 0$ & 1.9 & 1.5 & 1.8 & 12.2 & 0.5 & 0.5 & 0.5 & 0.0 & 0.1 & 0.3 & 66.7 \\
\hline 4 & ai-15:0 & 2.6 & 0.8 & 1.1 & 63.9 & 0.6 & 0.8 & 0.5 & 24.1 & 0.5 & 0.4 & 12.4 \\
\hline 5 & $n-15: 0$ & 1.6 & 1.5 & 0.8 & 32.5 & 0.7 & 0.9 & 1.1 & 22.2 & 0.9 & 0.6 & 29.0 \\
\hline 6 & $\mathrm{i}-16: 0$ & 1.7 & 0.5 & 0.7 & 65.9 & & & & & & & \\
\hline 7 & $9-16: 1$ & 3.5 & 0.7 & 1 & 90.3 & 2.3 & 1.9 & 1.3 & 27.5 & 3.2 & 1.7 & 48.5 \\
\hline 8 & $n-16: 0$ & 9.3 & 15.0 & 12 & 23.6 & 15.5 & 9.9 & 12 & 22.7 & 6.8 & 6.9 & 34.7 \\
\hline 9 & $8-17: 1$ & & & & & 0.6 & 0.9 & 0.9 & 21.7 & 1 & 1 & 6.0 \\
\hline 10 & i-9-17:1 & 2.5 & 0.7 & 1.1 & 69.5 & & & & & & & \\
\hline 11 & 10-Me-16:0 & 5.1 & 6.1 & 4 & 20.9 & & & & & & & \\
\hline 12 & $\mathrm{i}-17: 0$ & 1.9 & 0.7 & 0.9 & 57.5 & 0.3 & 0.2 & 0.7 & 66.1 & 0.7 & 0.4 & 28.9 \\
\hline 13 & ai-17:0 & 2.5 & 0.6 & 0.8 & 79.4 & 0.8 & 0.5 & 1.6 & 58.8 & 0.8 & 0.7 & 47.7 \\
\hline 14 & $9-17: 1$ & & & & & 0.2 & 0.1 & 1.6 & 132.4 & 0.5 & 0.5 & 73.3 \\
\hline 15 & $n-17: 0$ & 2 & 1.1 & 1.8 & 31.1 & 0.7 & 0.8 & 1 & 18.3 & 1 & 0.5 & 34.6 \\
\hline 16 & $6,9,12,15-18: 4$ & & & & & 0.1 & 4 & 3.7 & 83.5 & 1.2 & 0.3 & 101.6 \\
\hline 17 & $9,12-18: 2$ & 1.4 & 1.2 & 0.8 & 27.1 & 1.6 & 1.5 & 0.8 & 33.5 & 1.2 & 1 & 20 \\
\hline 18 & $5-18: 1$ & & & & & 6.6 & 7.8 & 2.8 & 45.5 & 3.3 & 3.2 & 8.5 \\
\hline 19 & $9-18: 1$ & 5.7 & 2.1 & 1.2 & 79.4 & 3.2 & 2.7 & 1.9 & 25.2 & 2.6 & 4.3 & 42.1 \\
\hline 20 & $\begin{array}{c}\text { 3,7,11,15-tetra- } \\
\text { Me-16:0 }\end{array}$ & 8.4 & 13.5 & 22.8 & 48.7 & & & & & & & \\
\hline 21 & $n-18: 0$ & 6.2 & 9.4 & 8.2 & 20.0 & 7.5 & 5.5 & 7.6 & 17.3 & 5.4 & 3.9 & 33 \\
\hline 22 & 15-Me-18:0 & & & & & 0.3 & 0.4 & 0.4 & 15.7 & 1.6 & 1 & 60 \\
\hline 23 & 11-Me-18:0 & 4.8 & 2.9 & 3.9 & 24.0 & & & & & & & \\
\hline 24 & i-19:0 & 1.5 & 0.6 & 0.7 & 49.6 & 0.2 & 0.2 & 0.2 & 0.0 & 0.7 & 0.2 & 78.7 \\
\hline 25 & i-19:0 & & & & & 0.1 & 0.2 & 0.2 & 34.6 & 0.7 & 0.3 & 66.1 \\
\hline 26 & $n-19: 0$ & & & & & 0.2 & 1.1 & 0.4 & 83.4 & 0.9 & 0.4 & 50.9 \\
\hline 27 & $5,8,11,14-20: 4$ & 2.5 & 1.7 & 3.7 & 37.2 & 1.2 & 1.1 & 2.1 & 37.6 & 3.7 & 7.1 & 59.4 \\
\hline 28 & $8,11,14,17-20: 4$ & 3 & 1.9 & 3.5 & 30.1 & 0.4 & 0.3 & 1.4 & 86.9 & 3.2 & 2 & 41.7 \\
\hline 29 & $8,11,14-20: 3$ & & & & & 0.1 & 0.4 & 0.5 & 62.5 & 1 & 0.6 & 37.8 \\
\hline 30 & $6,11-20: 2$ & & & & & 0.3 & 0.7 & 0.6 & 39.0 & 1 & 3.2 & 87.5 \\
\hline 31 & $13-20: 1$ & & & & & 0.3 & 0.6 & 0.3 & 43.3 & 1.3 & 0.8 & 62.5 \\
\hline 32 & n 20:0 & & & & & 0.9 & 1.1 & 1 & 10.0 & 2.7 & 1.4 & 52.3 \\
\hline 33 & $4,7,10,13,16,19-22: 6$ & & & & & 0.9 & 0.6 & 2.2 & 69.0 & 7.5 & 9 & 57.3 \\
\hline 34 & $7,10,13,16-22: 4$ & & & & & 0.1 & 0.3 & 0.2 & 50.0 & 1.1 & 0.6 & 71.2 \\
\hline 35 & $10,13,16,19-22: 4$ & & & & & 0.1 & 0.8 & 0.1 & 121.2 & 0.9 & 0.4 & 86.6 \\
\hline 36 & $n-22: 0$ & & & & & 1.3 & 0.9 & 0.9 & 22.3 & 1.6 & 0.5 & 55.7 \\
\hline 37 & $n-23: 0$ & 0.4 & 0.2 & 0.6 & 51.7 & 0.4 & 0.4 & 0.4 & 0.0 & 0.5 & 0.2 & 41.7 \\
\hline
\end{tabular}


Continued table 4.

\begin{tabular}{|c|c|c|c|c|c|c|c|c|c|c|c|c|}
\hline 38 & $17-24: 1$ & 0.8 & 0.6 & 0.5 & 20.1 & 1.8 & 1.8 & 1.3 & 17.7 & 3.3 & 3.8 & 47.2 \\
\hline 39 & $n-24: 0$ & 1.2 & 0.7 & 1.2 & 25.5 & 1 & 4.5 & 4.9 & 61.9 & 2.8 & 0.9 & 69.8 \\
\hline 40 & $i-5,9-26: 2$ & & & & & 0.1 & 0.1 & 0.4 & 86.6 & 2.2 & 0.8 & 83.4 \\
\hline 41 & $5,9-25: 2$ & 1.5 & 3.6 & 1.4 & 57.2 & 0.2 & 1 & 0.7 & 96.4 & 1.9 & 0.6 & 67.8 \\
\hline 42 & 19-Me-24:0 & 0.5 & 0.4 & 0.6 & 28.6 & & & & & & & \\
\hline 43 & $n-25: 0$ & 0.3 & 0.1 & 0.4 & 52.7 & & & & & & & \\
\hline 44 & $i-5,9-26: 2$ & 0.8 & 0.1 & 0.5 & 83.7 & & & & & & & \\
\hline 45 & $2-\mathrm{OH}-24: 0$ & 1.7 & 0.1 & 0.5 & 104.7 & & & & & & & \\
\hline 46 & $5,9-26: 2$ & 5.9 & 6.2 & 6.6 & 6.4 & 25 & 18.4 & 12.1 & 34.9 & 8.9 & 9.4 & 17.0 \\
\hline 47 & $9-26: 1$ & & & & & 2.6 & 2.5 & 0.4 & 84.6 & 2.8 & 0.6 & 105.1 \\
\hline 48 & 17-26:1 & 0.5 & 0.9 & 0.4 & 49.3 & 0.9 & 1 & 0.2 & 62.3 & 1.2 & 4.2 & 111.5 \\
\hline 49 & 19-26:1 & 0.2 & 0.6 & 0.3 & 48.6 & 0.4 & 1 & 0.6 & 45.8 & 1.3 & 4.1 & 92.6 \\
\hline 50 & $n-26: 0$ & 0.6 & 0.4 & 0.3 & 43.3 & 0.5 & 1.2 & 0.3 & 70.9 & 1.7 & 4.1 & 94.5 \\
\hline 51 & $5,9-27: 2$ & 1 & 0.6 & 0.6 & 33.8 & 2 & 3.1 & 0.9 & 55.0 & 2.4 & 2 & 44.0 \\
\hline 52 & $5,9-28: 2$ & & & & & 0.3 & 0.6 & 0.2 & 56.8 & 0.2 & 0.6 & 69.3 \\
\hline 53 & 19-Me-26:0 & 1.2 & 2.6 & 1.6 & 40.1 & & & & & & & \\
\hline 54 & $6-\mathrm{Br}-5,9-25: 2$ & 0.3 & 0.3 & 0.2 & 32.7 & & & & & & & \\
\hline 55 & $2-\mathrm{OH}-26: 2$ & 1.3 & 0.2 & 0.2 & 121.9 & & & & & & & \\
\hline 56 & $6-\mathrm{Br}-5,9-26: 2$ & 4.9 & 12.3 & 6.6 & 49.0 & 8.4 & 9.3 & 7.1 & 13.4 & 4.3 & 10.9 & 44.6 \\
\hline 57 & $6-\mathrm{Br}-5,9-27: 2$ & 1.3 & 2.0 & 0.9 & 40.4 & 1.3 & 1.8 & 1 & 29.6 & 1 & 2.1 & 46.5 \\
\hline
\end{tabular}

${ }^{*} A, B, C$ : different specimens of the same species in D. alvarezae.

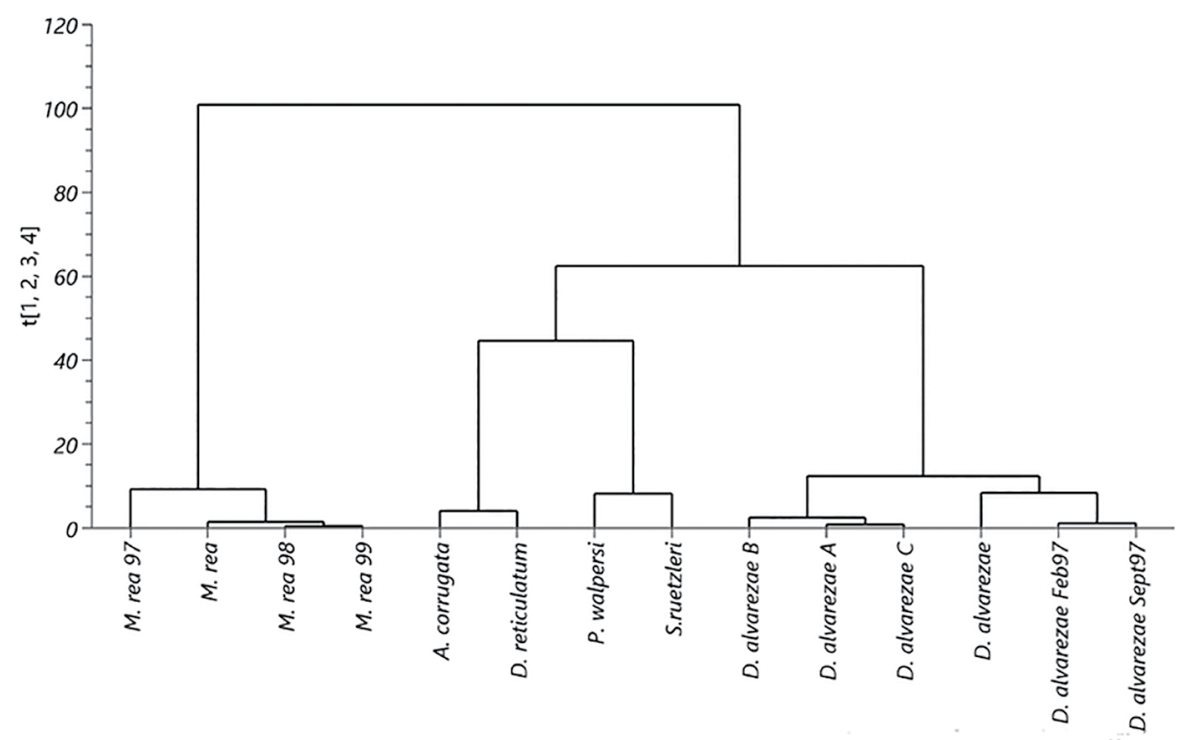

Figure 1. Hierarchical Clusters Analysis (HCA) of FA composition of the samples studied (data from Tables 3 and 4).

occurrence of iso- and anteiso- FA ( $>40 \%)$ suggests that the sponge cells are the principal producers of these lipids (Schreiber et al., 2006). In this study we reported low contents of these FA $(<23 \%)$, indicating a probable symbiont-sponge origin as was mentioned above (Table 3). It has been seen that high quantities of the 4,8,12-TMTD acid occur in calcareous sponges (Schreiber et al., 2006). Our results show that there was a predominance or specificity of 4,8,12-TMTD on phytanic acid or vice-versa. 
The presence of branched acids 4,8,12-TMTD and phytanic acid have been suggested as chemical markers for sponges of the families Spirastrellidae and Clionaidae; but also for Calcarea ( $<3 \%$ ) (Schreiber et al., 2006). A review on chemosystematics in sponges showed 4, 8, 12-TMTD acid was regarded unsuitable (Erpenbeck and van Soest, 2007). In our case, the overall FA composition, although species-specific to the point that it could perhaps be used as chemotaxonomic marker, did not serve to distinguish between the studied orders (Scopalinida and Axinellida).

Sponges are a prolific source of brominated FA; these compounds have been recognized as pancreatic lipase inhibitors with applications in obesity treatment (Br-PUFA) (Liang et al., 2014), and with activity against murine leukemia $L 1210$ cells and against human carcinoma KB cells (6-Br-5,9-27:2) (Bergé and Barnathan, 2005). In this study, the Caribbean sponges showed a lower content of FA bearing bromine ( $\leq 19 \%$, Table 3) compared to those found in the total lipid fraction of the sponges Axinella infundibuliformis (Axinellida, Axinellidae), Halichondria (Halichondria) genitrix (Suberitida, Halichondriidae), Phakellia ventilabrum (Axinellida, Axinellidae), Phakellia robusta (Axinellida, Axinellidae) and Axinella rugosa (Axinellida, Axinellidae) (6-75.9\%) collected in Norway (Blumenberg and Michaelis, 2007). Moreover, the FA of total lipids in Axinella rugosa collected in Korsfjord (Norway) in the autumn of 2001 (Blumenberg and Michaelis, 2007) had $38.5 \%$ long-chain fatty acids with bromine ( $\mathrm{Br}$-LCFA).

A fatty acid named 18-bromooctadeca-9E,17Ediene-7,15-diynoic acid and others similar FAs were identified in Xestospongia sp. with the atom Bromine position always at the end of hydrocarbon chain (Taniguchi et al., 2008) while in Haliclona sp, an FA was recorded with a structure of 6-bromo-icosa3Z,5E,8Z,13E,15E pentaene-11,19-diynoic acid, showing than more than twenty fatty acids with bromination at C- 6 have been reported in sponges (Aratake et al., 2009). All those results indicate that brominated fatty acids at C- 6 with system $\Delta^{5,9}$ in marine sponges seem to be restricted to the orders Agelasida, Haplosclerida and Tetractinellida. Interestingly, the FA content is lower for specimens collected in tropical waters compared to those collected in cold northern seas (Blumenberg and Michaelis, 2007). There is strong evidence of bromoperoxidase type enzyme activity in sponges belonging to the order Suberitida; these results should direct future work to experimentally characterize the specific enzymatic activity in marine sponges of this order (Blumenberg and Michaelis, 2007).

The C-2 methoxylated FA content reported here was lower than that reported in other marine sponges (Rod'kina, 2005) (Rodríguez et al., 2010). In general, the methoxy group was between chain lengths of $C_{15}$ to $C_{28}$ regardless of whether there were double bonds in the chain. Reported bioassays indicate that these compounds have potential as antimicrobial agents, but the full potential of the alpha methoxylated fatty acids as a therapeutic candidate remains to be determined (Carballeira, 2002). Recently very long-chain a-methoxylated $\Delta 5,9$ fatty acids from the Sponge Asteropus niger were shown to be effective inhibitors of topoisomerases IB (Carballeira et al., 2016). On the other hand, the $C-2$ hydroxylated FA content registered here was lower than that reported in other marine sponges (Rod'kina, 2005).

With respect to the seasonal and intraspecific variation of fatty acids presented here, as the food source determines FA content in sponges, the sponge FA composition will change when the food source changes (Koopmans et al., 2014). In Colombia, a year has two seasons: rainy and dry seasons. The rainy season runs from April to May and October to November, and the dry season is usually December to January and July to August, although this can vary considerably. During the rainy season, more sediment reaches the sea, and more food is available for the sponges. To assess the effect of the seasons, the FA composition of the phospholipid fraction was determined for M. rea and D. alvarezae (Table 4).

Studies on the effect of seasonal and geographical variation in the composition of marine and freshwater sponge fatty acids are scarce. A study on seasonal variation in the contents of demospongic acids (C24-C28) in sponges from the Sea of Japan, collected between January and July, revealed variability ranging from $24 \%$ to $30 \%$ for the C24:0 fatty acid contents for the sponge Semisuberites cribrosa. The fatty acids with a chain length of C25:1 in Semisuberites cribrosa, C26:2 in Haliclona (Reniera) cinerea and C28:0 in Suberites domuncula presented a $\mathrm{CV}<15 \%$, while other fatty acids had variations ranging from $30 \%$ to $100 \%$ 
(Lüskow et al., 2019). However, the seasonal fluctuation of fatty acid composition is also common in marine sponges and is an adaptive response of the sponge to optimize membrane flexibility at different environmental temperatures (Lüskow et al., 2019) which probably partly explains the high FA content variations encountered in our study (Table 4).

\section{CONCLUSIONS}

We identified $F A$ with chain length from $C_{14}$ to $C_{32}$; there was a predominance of iso-acids (i-15:0 and i-17: 0) on anteiso acids within sponge studied suggesting a high predominance of bacteria as symbionts in these sponges. Our results show that there was a predominance or specificity of $4,8,12$-TMTD on phytanic acid or vice-versa, regardless of the studied taxon level between studied sponges. In this study, the Caribbean sponges showed a lower content of FA bearing bromine compared with those from the Nordic sea. The seasonal variations in the phospholipid fatty acid contents ranged from CV 6.0-106.1\%. The intraspecific variation on the phospholipid fatty acid contents ranged from CV $0-132.4 \%$. FA composition could be used as a chemo-taxonomic marker for each of the studied species, even across temporal and individual variation, the latter for the sponges Dragamacidon alvarezae and Myrmekioderma rea. However, at the family and order level, FA composition appears not to be informative.

\section{ACKNOWLEDGMENTS}

The authors thank COLCIENCIAS and Universidad Nacional de Colombia for its financial support. S.Z. word is contribution XXX of Instituto de Estudios en Ciencias del Mar - CECIMAR, Universidad Nacional de Colombia, Caribbean campus.

\section{AUTHOR CONTRIBUTIONS}

W. R.: Methodology, Investigation, writing-review \& editing

S. Z.: Conceptualization, Investigation, writing-review \& editing

L. C., C. D, O. O.: Conceptualization, Resources, Project Administration; Funding Acquisition; writing-review \& editing

F. R., A. F.: Formal analysis, writing-review \& editing

\section{REFERENCES}

ARATAKE, S., TRIANTO A., HANIF, N., DE VOOGD, N. J. \& TANAKA, J. 2009. A new polyunsaturated brominated fatty acid from a Haliclona sponge. Marine Drugs, 7(4), 523-527.

BENNETT, H., BELL, J. J., DAVY, S. K., WEBSTER, N. S. \& FRANCIS, D. S. 2018. Elucidating the sponge stress response; lipids and fatty acids, can facilitate survival under future climate scenarios. Global Change Biology, 24(7), 3130-3144.

BERGÉ, J. P. \& BARNATHAN, G. 2005. Fatty acids from lipids of marine organisms: Molecular biodiversity, roles as biomarkers, biologically active compounds, and economical aspects. Advances in Biochemical Engineering/Biotechnology, 96, 49-125.

BLUMENBERG, M. \& MICHAELIS, W. 2007. High occurrences of brominated lipid fatty acids in boreal sponges of the order Halichondrida. Marine Biology, 150(6), 1153-1160.

CAMPOS, P. E. PICHON, E., ILLIEN, B., CLERC, P., MORIOU, C., DE VOOGD, N., HELLIO, C., TRÉPOS R., FREDERICH, M., ALMOURABIT, A. \& GAUVIN-BIALECKI, A. 2018. (2S*,5S*,6Z)-2,5epoxydocosan-6-en-21-ynoic acid, new fatty acid from the marine sponge Haliclona fascigera. Natural Products Chemistry \& Research, 6(5), 19-22.

CARBALLEIRA, N. M. 2002. New advances in the chemistry of methoxylated lipids. Progress in Lipid Research, 41(6), 437-456.

CARBALLEIRA, N. M. 2008. New advances in fatty acids as antimalarial, antimycobacterial and antifungal agents. Progress in Lipid Research, 47(1), 50-61.

CARBALLEIRA, N. M., CARTAGENA, M., LI, F., CHEN, Z., PRADA, C. F., CALVO-ALVAREZ, E., REGUERA, R. M. \& BALAÑA-FOUCE, R. 2012. First total synthesis of the ( \pm )-2-methoxy-6-heptadecynoic acid and related 2-methoxylated analogs as effective inhibitors of the leishmania topoisomerase IB enzyme. Pure and Applied Chemistry, 84(9), 1867-1875.

CARBALLEIRA, N. M., MONTANO, N., AMADOR, L. A., RODRIGUEZ, A. D., GOLOVKO, M. Y., GOLOVKO, S. A., REGUERA, R. M, VELILLA-ÁLVAREZ, R. \& BALAÑA-FOUCE, R. 2016. Novel very long-chain a-methoxylated $\delta 5,9$ fatty acids from the sponge Asteropus Niger are effective inhibitors of topoisomerases IB. Lipids, 51(2), 245-256.

CARBALLEIRA, N. M., MONTANO, N., VICENTE, J. \& RODRIGUEZ, A. D. 2007. Novel cyclopropane fatty acids from the phospholipids of the Caribbean sponge Pseudospongosorites suberitoides. Lipids, 42(6), 519-524.

CASTELLANOS, L. \& DUQUE, C. 2008. Composición química y actividad antifouling de la fracción lipídica de la esponja marina Cliona tenuis (Clionidae). Revista Colombiana de Quimica, 37(3), 259-274.

ERPENBECK, D. \& VAN SOEST, R. W. M. 2005. A survey for biochemical synapomorphies to reveal phylogenetic relationships of halichondrid demosponges (Metazoa: Porifera). Biochemical Systematics and Ecology, 33, 585-616.

ERPENBECK, D. \& VAN SOEST, R. W. M. 2007. Status and perspective of sponge chemosystematics. Marine Biotechnology, 9(1), 2-19.

IMBS, A. B. \& RODKINA, S. A. 2004. Isolation of 2-methyl branched unsaturated very long fatty acids from marine sponge Halichondria panicea and identification of them by GC-MS and NMR. Chemistry and Physics of Lipids, 129(2), 173-181. 
KALIDASAN, K., SAHU, S. K., KAYALVIZHI, K. \& KATHIRESAN, K. 2015. Polyunsaturated fatty acid-producing marine thraustochytrids: a potential source for antimicrobials. Journal of Coastal Life Medicine, 3(11), 848-851.

KLUIJVER, A., NIEROP, K. G. J., MORGANTI, T. M., BART, M. C., SLABY, B. M., HANZ, U., GOEIJ, J. M., MIENIS, F. \& MIDDELBURG, J. J. 2021. Bacterial precursors and unsaturated long-chain fatty acids are biomarkers of North-Atlantic deep-sea demosponges. PLoS One, 16(1), e0241095.

KOOPMANS, M., VAN RIJJSWIJK, P., BOSCHKER, H.T. S., HOUTEKAMER, M., MARTENS, D. \& WIJFFELS, R. H. 2015. Seasonal variation of fatty acids and stable carbon isotopes in sponges as indicators for nutrition: biomarkers in sponges identified. Marine Biotechnology, 17, 43-54.

KORNPROBST, J. M. \& BARNATHAN, G. 2010. Demospongic acids revisited. Marine Drugs, 8(10), 2569-2577.

LIANG, L. F., WANG, T., CAI, Y. S., HE, W. F., SUN, P., LI, Y. F., HUANG, Q., TAGLIALATELA-SCAFATI, O., WANG, H. Y. \& GUO, Y. W. 2014. Brominated polyunsaturated lipids from the Chinese sponge Xestospongia testudinaria as a new class of pancreatic lipase inhibitors. European Journal of Medicinal Chemistry, 79, 290-297.

LIPID MAPS . 2021. Lipidomics gateway [online]. Gilman Drive, CA: UCSD - University of California San Diego. Available at: https://www.lipidmaps.org/ [Accessed: 23 Jan. 2021].

LÜSKOW, F., KLøVE-MOGENSEN, K., TOPHØJ, J., PEDERSEN, L. H., RIISGÁRD, H. U. \& ERIKSEN, N. T. 2019. Seasonality in lipid content of the demosponges Halichondria panicea and $\mathrm{H}$. bowerbanki at two study sites in temperate Danish waters. Frontiers in Marine Science, 6(328), 1-7.

MJøS, S. A. 2004. The prediction of fatty acid structure from selected ions in electron impact mass spectra of fatty acid methyl esters. European Journal of Lipid Science and Technology, 106(8), 550-560.

MOHAMAD, H., NAJMIAH, W. A., JAMIL, W. A., ABAS, F., MOHAMAD, K. S. \& ALI, A. M. 2009. Octacosanoic acid, long chains saturated fatty acid from the marine sponges Xestospongia sp. Pertanika Journal of Tropical Agricultural Science, 32(1), 51-55.

NECHEV, J., CHRISTIE, W. W., ROBAINA, R., DIEGO, F., POPOV, S. \& STEFANOV, K. 2004. Chemical composition of the sponge Hymeniacidon sanguinea from the Canary Islands. Comparative Biochemistry and Physiology - A Molecular and Integrative Physiology, 137(2), 365-374.

ORELLANO, E. A., CARTAGENA, M. M., ROSADO, K. \& CARBALLEIRA, N. M. 2013. Synthesis of the novel ( \pm )-2-methoxy-6-icosynoic acid-a fatty acid that induces death of neuroblastoma cells. Chemistry and Physicsof Lipids, 172-173, 14-19.

RABIN, N., ZHENG, Y., OPOKU-TEMENG, C., DU, Y., BONSU, E. \& SINTIM, H. O. 2015. Agents that inhibit bacterial film formation. Future Medicinal Chemistry, 7(5), 647-671.
ŘEZANKA, T. \& SIGLER, K. 2009. Odd-numbered very-long-chain fatty acids from the microbial, animal and plant kingdoms. Progress in Lipid Research, 48(3-4), 206-238.

RODKINA, S. A. 2005. Fatty acids and other lipids of marine sponges. Russian Journal of Marine Biology, 31, S49-S60.

RODRÍGUEZ, W., OSORNO, O., RAMOS, F. A., DUQUE, C. \& ZEA, S. 2010. New fatty acids from Colombian Caribbean Sea sponges. Biochemical Systematics and Ecology, 38(4), 774783.

SANTALOVA, E. A. \& DENISENKO, V. A. 2017. Fatty acids from a glass sponge Aulosaccus sp. occurrence of new cyclopropane-containing and methyl-branched acids. Lipids, 52(1), 73-82.

SCHREIBER, A., WÖRHEIDE, G. \& THIEL, V. 2006. The fatty acids of calcareous sponges (Calcarea, Porifera). Chemistry and Physics of Lipids, 143(1-2), 29-37.

TANIGUCHI, M., UCHIO, Y., YASUMOTO, K., KUSUMI, T. \& OOI, T. 2008. Brominated unsaturated fatty acids from marine sponge collected in Papua New Guinea. Chemical and Pharmaceutical Bulletin, 56(3), 378-382.

VAN DUYL, F. C., LENGGER, S. K., SCHOUTEN, S., LUNDÄLV, T., VAN OEVELEN, D. \& MÜLLER, C. E. 2020. Dark $\mathrm{CO}_{2}$ fixation into phospholipid-derived fatty acids by the cold-water coral associated sponge Hymedesmia (Stylopus) coriacea (Tisler Reef, NE Skagerrak). Marine Biology Research, 16(1), 1-17.

VEGA-SEQUEDA, J., RODRÍGUEZ-RAMÍREZ, A., REYES-NIVIZ, C. \& NAVAS-CAMACHO, R. 2008. Formaciones coralinas del área de Santa Marta: Estado y patrones de distribución espacial de la comunidad bentónica. Boletin de Investigaciones Marinas y Costeras, 37, 87-105.

YANG, Y. H., DU, L., HOKOSAWA, M., MIYASHITA, K., KOKUBUN, Y., ARAI, H. \& TARODA, H. 2017. Fatty acid and lipid class composition of the microalga Phaeodactylum tricornutum. Journal of Oleo Science, 66(4), 363-368.

ZEA, S. \& PULIDO, A. 2016. Taxonomy of the Caribbean sponge Dragmacidon reticulatum (Ridley \& Dendy, 1886) (Porifera, Demospongiae, Axinellida), with the description of a new species. Zootaxa, 4114(4), 393-408.

ZHANG, L. X., Jl, X. Y., TAN, B. B., LIANG, Y. Z., LIANG, N. N.,WANG, X. L. \& DAl, H. 2010. Identification of the composition of fatty acids in Eucommia ulmoides seed oil by fraction chain length and mass spectrometry. Food Chemistry, 121(3), 815819.

ZIVANOVIC, A., PASTRO, N. J., FROMONT, J., THOMSON, M. \& SKROPETA, D. 2011. Kinase inhibitory, haemolytic and cytotoxic activity of three deep-water sponges from North Western Australia and their fatty acid composition. Natural Product Communications, 6(12), 1921-1924. 